\title{
Remote Sensing and Land Use/Land Cover Trajectories
}

\author{
Mukesh Singh Boori* and Vít Voženílek \\ Palacky, University Olomouc, 17. Listopadu 50, 77146 Olomouc, Czech Republic
}

\begin{abstract}
Remotely sensed data is the most important data source for land cover change trajectories over the past 40 years. This research explores the temporal composition of the main Land-use/land-cover (LULC) trajectories. Examine the spatial configuration of the trajectory derive the probability of transitions in the Olomouc region, Czech Republic. Multi-temporal satellite data from 1991, 2001 and 2013 were used to extract land use/cover types by object oriented classification method. To achieve the objectives, three different aspects were used: (1) Calculate the quantity of each transition; (2) Allocate location based landscape pattern (3) Compare land use/cover evaluation procedure. Land cover change trajectories show that $16.69 \%$ agriculture, $54.33 \%$ forest and $21.98 \%$ other areas (settlement, pasture and water-body) were stable in all three decade. Approximately $30 \%$ of the study area maintained as a same land cove type from 1991 to 2013. The results suggest that spatial pattern metrics of land cover change trajectory can provide a good quantitative measurement for better understanding of the spatio-temporal pattern of land cover change due to different causes.
\end{abstract}

Keywords: Remote sensing; Land use/cover; Change trajectories; Image classification

\section{Introduction}

Socio-economic activities have been one of the most important factors for land cover change trajectories. In place of two dates of change in satellite imageries, researchers are more focus on temporal land cover change trajectories [1-3]. In European Union (EU) 43\% land is farmland, 26\% arable and for Czech Republic it s 54\% and 37\% respectively [4]. Only $17 \%$ of farmland is farmed by the landowners and this is the second lowest in EU (Eurostat). Within Europe growing environmental problems in recent decades frequently ensue from dominant trends in the current use of agricultural land [4]. Earlier land cover change in Czech Republic have analysed by many authors. These studies focused on the influence of extreme fragmentation of agricultural land, their ownership and rural landscape patterns $[5,6]$. Historical maps reaching back to the mid- $18^{\text {th }}$ century were used by [7] to analyse long-term land-cover changes in 21 cadastral units of Central Bohemia, Czech Republic. They mention that $18 \%$ to $5 \%$ permanent grassland and $6 \%$ to less than $1 \%$ surface water area were decreased in Czech Republic.

Trajectory analysis is a new method for land cover change research based on each pixel's in time series [8] developed a trajectory-based hierarchical decision tree to delineate Warm Season Grass (WSG) and Cool Season Grass (CSG) for long term WSG/CSG mapping. Temporal trajectory is using to discover land use/cover change trends by constructing the 'curves' or 'profiles' of multi-temporal data [9]. The concept of trajectory to change has attracted some attention from a theoretical viewpoint. These trajectories defined as trends over time among the relationships between the factors. These factors shape the changing nature of human-environment relation and their effects within a particular region $[10,11]$. This takes widely different forms and depends on circumstances, regional contexts, and government policies. These studies have further highlighted the importance of understanding landscape dynamics for sustainability and conservation purposes $[12,13]$.

\section{Study Area}

The study area cover Olomouc region, which is located in northeastern Czech Republic between $49^{\circ} 45^{\prime} \mathrm{N}$, and $17^{\circ} 15^{\prime} \mathrm{E}$ (Figure 1). The border between the Olomouc Region and Poland in the north is 104 $\mathrm{km}$ long. The other neighbours are the Moravskoslezský Region in the east, the Zlín Region and the Jihomoravský Region in the south and the Pardubický Region in the west. The geographical layout of the region is rather unusual. There are lowlands at the Polish borders, followed by the Jeseníky mountain range with Praděd (map) the highest mountain (1,492 $\mathrm{m}$ above sea level), while the southern part (again) comprises lowlands-the flat and fertile land of Haná. This region is one of the most fertile areas of the Czech Republic. Its elevation is $219 \mathrm{~m}(719 \mathrm{ft})$ and total area is $103.36 \mathrm{~km}^{2}$. Its total population is 101,003 with $987 / \mathrm{km}^{2}$ density (Figure 1).

This region is characterised by coniferous forests (Pinus sylvestris $\mathrm{L}$. and Picea abies L. Karst.) and large aapa mires. Deciduous trees mainly Betula $s p p$. occur to a lesser extent and located in the northern boreal vegetation zone. Highest fells and alpine vegetation are found in the north-western part of the study region in the Jeseniky mountain area. A large number of lichen pastures with forest are located in the eastern and north-eastern mountainous part of the Olomouc region. The most important late winter pastures with arboreal lichens are located in the western, central and southern parts of the Olomouc Region [14]. Summer and autumn pasture with vegetation are consisting in mires, lake and riversides. Moist forest and fresh forest are present in the north-eastern, south-western, eastern and western parts of the Olomouc Region [15].

\section{Methodology}

Remote sensing data are particularly useful due to the cost and time associated with traditional survey methods $[16,17]$. These techniques have become viable alternatives to conventional survey and ground-

*Corresponding author: Mukesh Singh Boori, Palacky University Olomouc, 17. Listopadu 50, 77146 Olomouc, Czech Republic, Tel: 420585634519; E-mail: mukesh.boori@upol.cz

Received May 21, 2014; Accepted June 11, 2014; Published June 18, 2014

Citation: Boori MS, Voženílek V (2014) Remote Sensing and Land Use/Land Cover Trajectories. J Geophys Remote Sensing 3: 123. doi:10.4172/2169-0049.1000123

Copyright: @ 2014 Boori MS, et al. This is an open-access article distributed under the terms of the Creative Commons Attribution License, which permits unrestricted use, distribution, and reproduction in any medium, provided the original author and source are credited. 


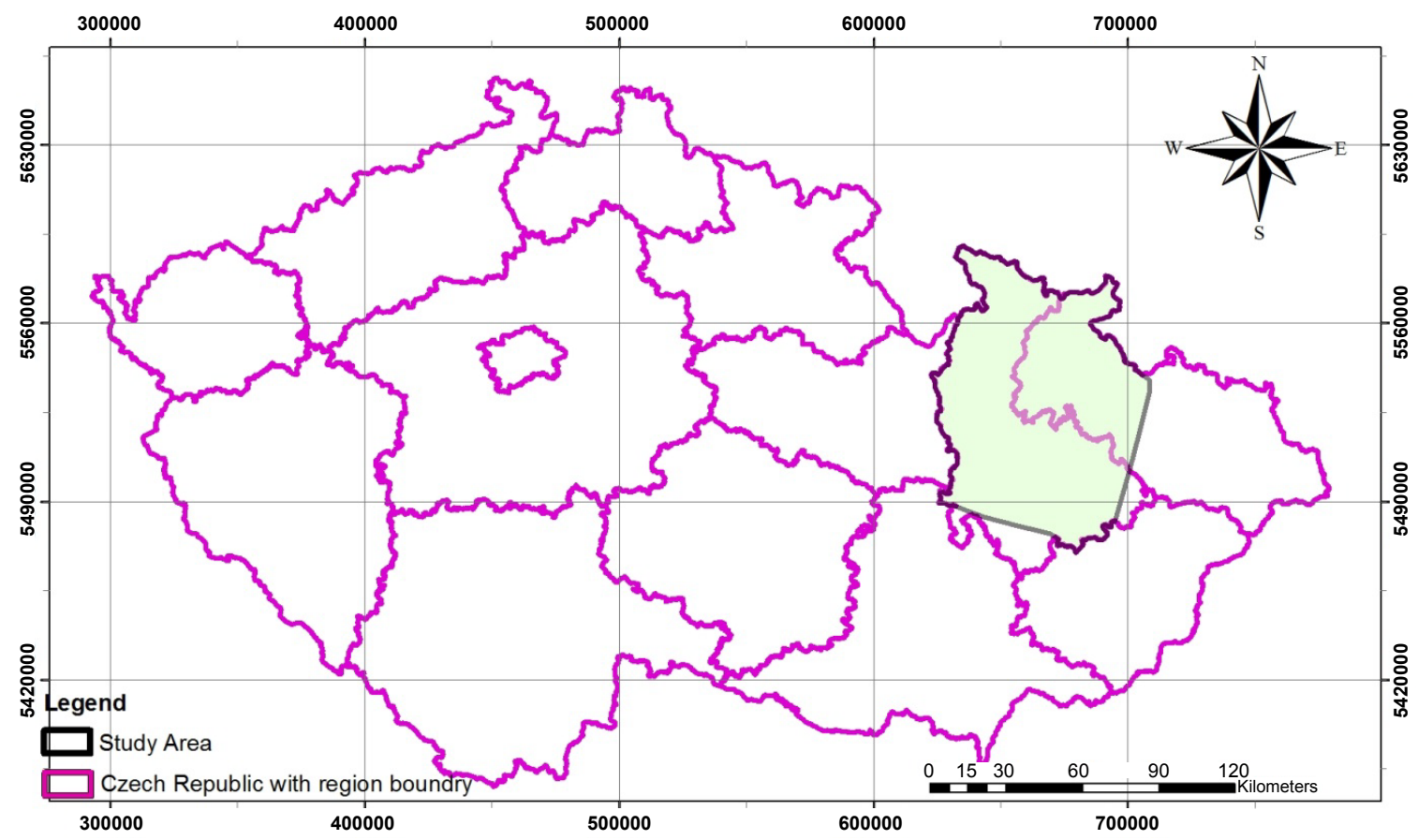

Figure 1: Study area:Jeseniky mountain region, Olomouc.

based mapping methods [16]. Remote sensing and Geographic Information System is a powerful and effective tool to assess the spatial and temporal dynamics of landscape trajectories $[17,18]$. Remote sensing data provide valuable multi-temporal information of the processes and patterns of land cover change. GIS is useful for mapping and analysing these patterns [19]. In addition, retrospective and consistent synoptic coverage from satellites is particularly useful in areas, where changes have been rapid [20]. Furthermore, since digital archives of remotely sensed data provide the opportunity to study historical land use/cover changes, the geographic pattern of such changes in relation to other environmental and human factors can be evaluated. In addition, accurate and comprehensive land cover change trajectories statistics are useful for devising sustainable development and planning strategies [21,22]. It is therefore very important to estimate the rate, pattern and type of land cover change trajectories in order to predict future changes for sustainable development.

This paper present land cover change trajectories analysis for forest, agriculture and others (settlement, pasture and water body) for three decades (1991, 2001 and 2013) in the Olomouc, Czech Republic. This research seeks to: (1) Capture the spatio-temporal variability of landscape change trajectories in Olomouc, (2) Comparing RS, GIS and socio-economic factors in Olomouc.

\section{Data and Image Classification}

NASA Landsate TM and ETM+data (1991, 2001 \& 2013) were used for land cover change trajectory, as it's free of cost. ArcGIS 10.1 software was used for all image preparation, spatial analysis and mapping. Topographic database provides the most accurate and uniform information for map products covering the entire country so geographic corrections were performed on the base of topographic sheets and then registered (UTM WGS84) all images. 26 ground control points (GCPs) were used for registration. All GCPs were dispersed throughout the scene, yielding a RMS error of less than 0.5 pixels. The photographs were acquired with a frame camera that was designed to support mapping, charting and geodesy in addition to two high-resolution cameras. Aerial photographs from 2013 were also used for ground truth in land cover classification. All bands except thermal band were used for classification.

Pre- and post-classification comparison techniques have been extensively used $[23,24]$. In the pre-classification approach procedure such as image differencing [25], band rationing [26], change vector analysis [27], direct multi-date classification [28], vegetation index differencing [29] and principle component analysis [30] have been developed [31]. These techniques are useful for locating the change but they are unable to identify nature of change [32,33]. After pre-processing and geometric correction, all satellite images used for classification to know changes in between two dates in the study area. A number of methods are available for temporal land use change detection, including: (i) post-classification comparison, (ii) classification of multitemporal data sets, (iii) principal components analysis (PCA), (iv) temporal image differencing and rationing, (v) change vector analysis and (vi) spectral mixture analysis. The main emphasis of the study was on change in natural forest cover (i.e. deforestation) and areas under intensive cultivation. In satellite image classification, vegetated area was comprised mixture of surface materials such as different canopy components, bare soil, water and shadow. The spectrum measured by the sensor was therefore a mixture of each of these components [34].

This research work report the finding of post-classification comparison between two dates images in the study area. First unsupervised classification and then supervised maximum likelihood classification (MLC) were used to obtain the best results from remotely sensed data. Gaussian distribution [35] was applied in each image. In supervised classification training sites were based on reference data and ancillary information. In last, post-classification refinement was used to improve the accuracy of classification. Three major land cover classes were identified: forest, agriculture and others (water body, pasture and 
settlements). In this research work three land cover classes for three time nodes were used in the trajectory analysis to monitor land use/ cover change dynamics.

We used simple metrics for quantifying the landscape structure and their behaviour predicated across all evaluation [36,37]. In ArcGIS, an iterative multi-objective land allocation procedure was used to resolve conflicts decision heuristic and carried out change trajectories over the landscape. The definition of forest cover was minimum $30 \%$ canopy coverage which provides a distinct delineation between scrub areas and dene forest. Follow-up field work was conducted in October 2013 and February 2014, to determine ambiguous land-cover classification. Visit study area to determine major changes and there causes by observations and informal interviews of local people. This also provided a secondary validation of the classification accuracy for the most current image date.

\section{Results}

In the image classification agriculture land makes up the largest percent of the Olomouc region with $37 \%, 42 \%$, and $39 \%$ respectively for 1991, 2001, and 2013 (Figure 2). Forest makes up the next largest land-cover, and occurs predominantly in the more upland areas with greater relief. Forest area decrease dramatically during the first half of the study period from $40 \%$ to $29 \%$ but then rigid to $35 \%$ during the second half of the study. Other classes make up around $25 \%$ of the all over the study area for last three decades.

Figure 2 illustrates the land cover classification results of the study area. This comprehensive analysis of land cover provides both the timing and nature of land cover changes. To simplify for illustration purposes, we categorised three major categories of land cover classes: forest, agriculture and others (settlement, water body and pasture). For example, we can easily derive information since past 30 years. The largest loss of forest was from forest to develop and the largest gain of forest was from barren to forest in the study area. It can also provide new kinds of information about what kind of land cover change occurred on a yearly basis for the entire scene.

The changes that occurred at these pixels were obvious when viewed from the perspective of the entire time series. This approach allows the identification of the timing of each change, as well as the kind of change. When the time series has been built for a pixel and analysed for change, it is possible to use the estimated time series models between the changes to identify the land cover class for the pixel at different time periods. For the pixel located at first year, the estimated model preceding the change in 1991 can be used to classify the land cover for the entire time prior to the change. Similarly the estimated method subsequent to the change can be used to identify what land cover came after the change in 1991. The shape of the time series method can be

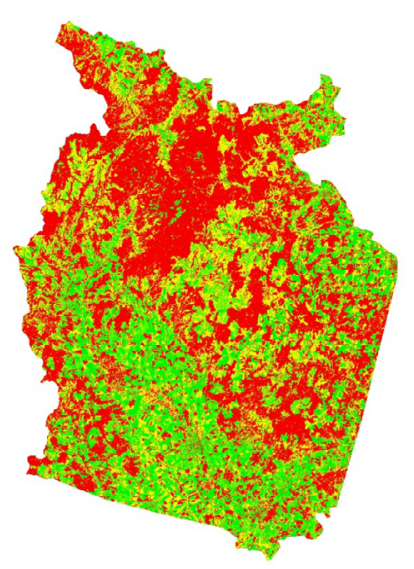

1991

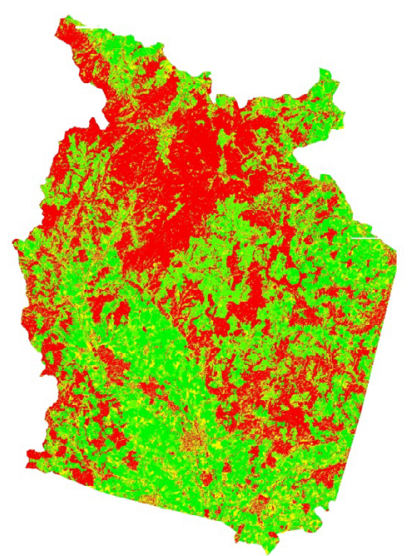

2013

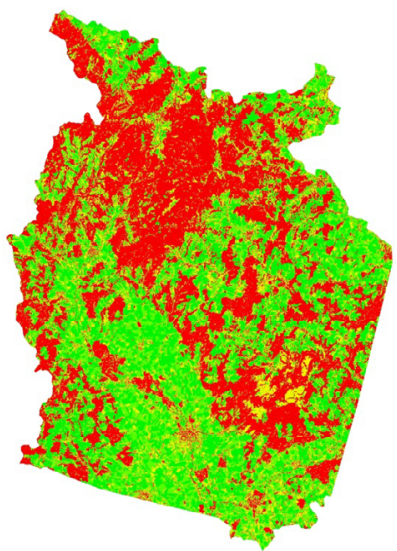

2001
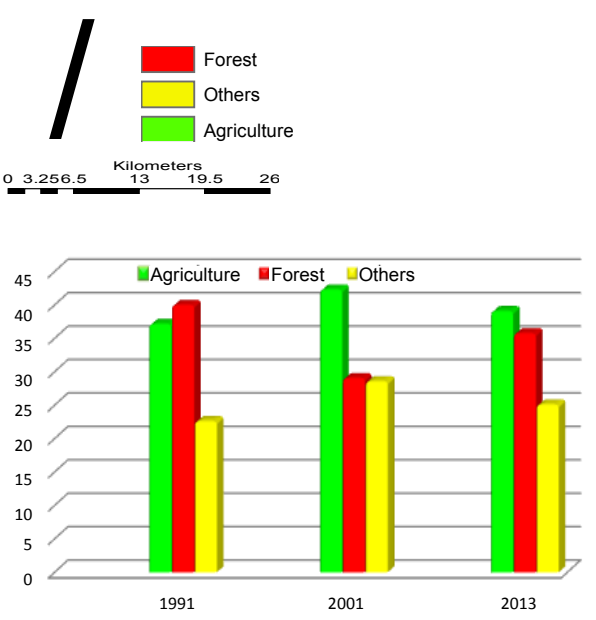

Figure 2: Land cover classification for the Olomouc region for 1991, 2001, and 2013. 
very helpful in land cover classification which is evident in the time series graphs at the bottom, as initially pixels located in year 1991 and 2013 were conifer forest and pixel located in 2001 was a hardwood forest, and they are readily distinguishable by the difference in the amplitude of their time series (Table 1).

\section{Change detection}

Figure 2 shows the land cover classifications produced for 1991, 2001 and 2013 from Landsat images, and Figure 3 shows the areas of forest addition and removal. Table 1 provides the areas of each class. The total area of the study is $2000 \mathrm{~km}^{2}$. From Figure 2, it is clear that most of the forest is in the northern part of the study area, which has higher elevation and higher rainfall intensity. This area has larger trees, suitable for timber production and is closer to major urban areas, such as Bruntál, Šumperk, Jeseník, Rýmařov. In this area, new forest area added but this was less than what has been removed. In the flat southern region, Figure 3 shows that more forest has been removed than added, but the extent of this change was small compared to the changes in the north. The spatial analysis in relation to socio-economic activities confirms this (Figure 3 ).

Change trajectories between the years 1991, 2001, and 2013 were compared on a pixel-by-pixel basis to examine possible landcover disturbance (Table 2). Thirty three percent of the landscape remained in the same land-cover class from 1991 to 2013. Two-date changes (1991-2001 and 2001-2013) show that, $2300 \mathrm{~km}^{2}$ forest and $1500 \mathrm{~km}^{2}$ agriculture area was stable in last two decades. $140 \mathrm{~km}^{2}$ agriculture, $20 \mathrm{~km}^{2}$ forest and $18 \mathrm{~km}^{2}$ pasture area were encroached by settlements from 2001 to 2013. In 2001, $260 \mathrm{~km}^{2}$ other classes and 480 $\mathrm{km}^{2}$ agriculture area added in forest area. $313 \mathrm{~km}^{2}$ others and $127 \mathrm{~km}^{2}$ agriculture areas were removed from forest area from 1991 to 2001. $118 \mathrm{~km}^{2}$ agriculture and $245 \mathrm{~km}^{2}$ other class area added in forest class. Stable forest cover area was mostly located in high elevation area of the mountain, especially in Jesenilk, Bruntal, Sumperk and Rymarov.

\begin{tabular}{|c|c|c|c|c|c|c|}
\hline Class & $\mathbf{1 9 9 1}$ & $\mathbf{\%}$ & $\mathbf{2 0 0 1}$ & $\mathbf{\%}$ & $\mathbf{2 0 1 3}$ & $\%$ \\
\hline Agriculture & 743.23 & 37.16 & 846.57 & 42.32 & 781.9 & 39.09 \\
\hline Forest & 804.02 & 40.02 & 581.49 & 29.07 & 715.61 & 35.78 \\
\hline Others & 452.48 & 22.62 & 571.94 & 28.59 & 502.49 & 25.12 \\
\hline Total & 2000 & & 2000 & & 2000 & \\
\hline
\end{tabular}

Table 1: Results of land use/land cover classification for 1991, 2001 and 2013 images showing area of each category and class percentage.

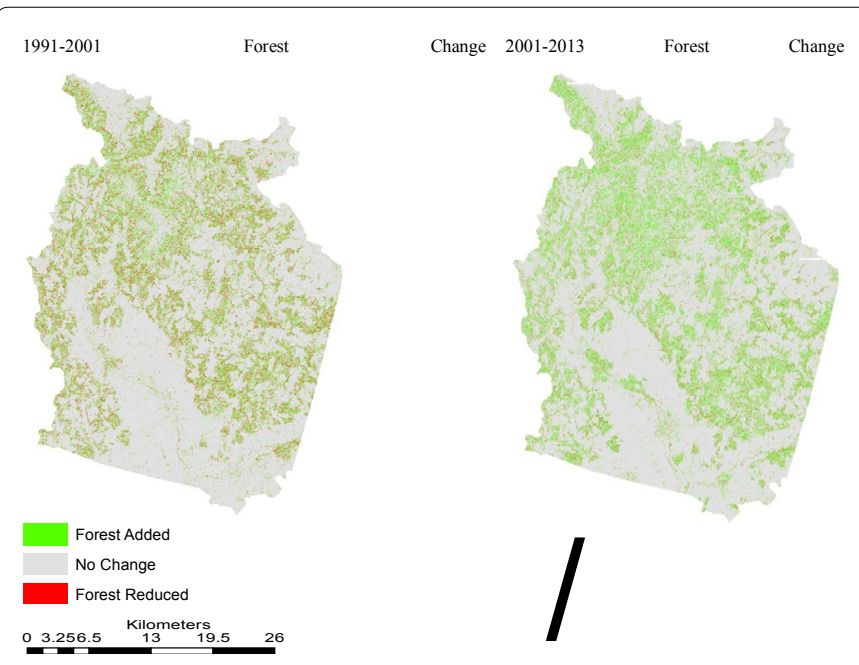

Figure 3: Increase and decrease in forest cover

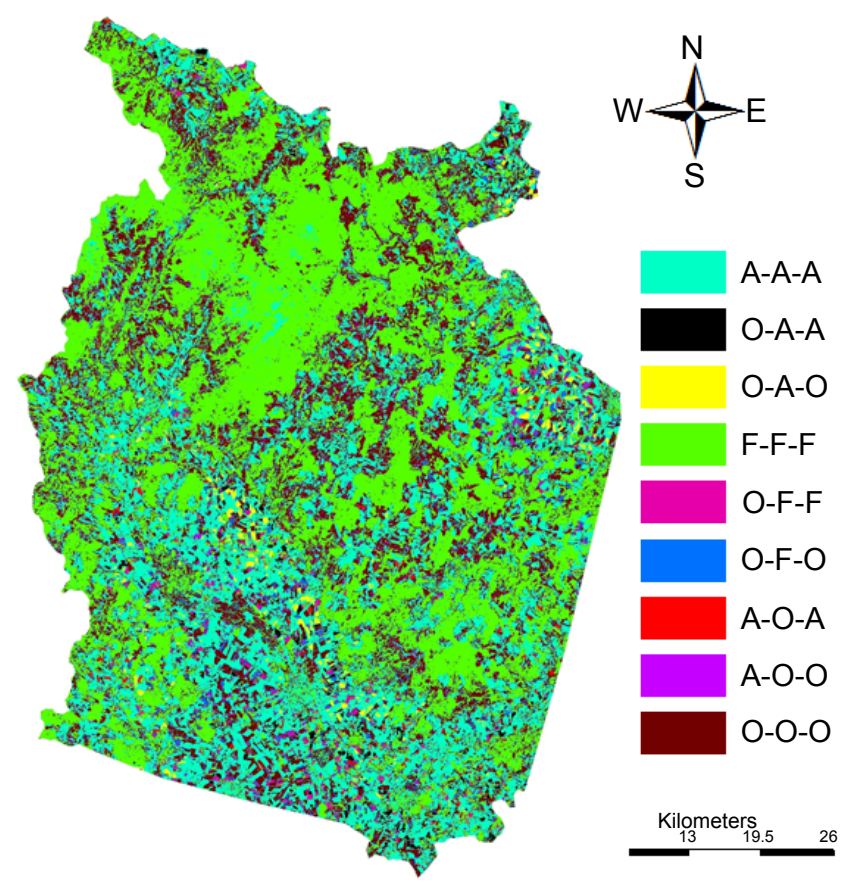

Figure 4: Land-cover classification trajectories for 1991-2001-2013 in the Olomouc. "F" refers to forest, "A" agriculture and "O" to other classes (pasture, settlements, water body).

This study employed the post-classification change detection technique, which was efficient in detecting the nature, rate and location of changes, and has been successfully used by a number of researchers in the study of natural resources [31]. An overlay procedure using the GIS was adopted in order to obtain the spatial changes in land cover during two intervals: 1991-2001 and 2001-2013. Application of this technique resulted in a two-way cross-matrix, describing the main types of change in the study area. Cross tabulation analysis on a pixel-bypixel basis facilitated the determination of the quantity of conversions from a particular land cover class to other land use categories and their corresponding area over the period evaluated. A new thematic layer containing different combinations of "from-to" change classes was also produced for each of the two three-class maps (Table 2).

Using the Landsat datasets, we calculated producer accuracy for all potential change pixels at three decade time steps. In the study area, within-class and between-years reveal different characteristics of change. Figure 3 shows examples of within-class and between-years changes from 1991-2001 and 2001-2013. The within-class distances appear to highlight the contrast between forest and non-forest areas in a given year. The between-year changes are noisier, but highlight locations with large differences between two years including newly changed areas and agricultural areas that were inherently more variable.

\section{Analysis based on trajectories}

This three decade trajectory analysis was focus on forest, agriculture and different factors drive changes in the region. Two-date changes (1991-2001 and 2001-2013) show stable non-forest (agriculture and others) area cover over $38 \%$ landscape while stable forest cover (F-F) drops from 54\% (Table 3). In the study area old permanent agriculture regrowth and regrowth with new clearing class was $1.07 \%$ of the total area. Forest regrowth with new clearing and old permanent forest regrowth area was around $4 \%$ of the total area. Old permanent 


\begin{tabular}{|c|c|c|c|c|c|c|c|c|c|}
\hline 1991-2001 & Forest & Others & Agriculture & Total & $\mathbf{2 0 0 1 - 2 0 1 3}$ & Forest & Others & Agriculture & Total \\
\hline Forest & 2340 & 313 & 127 & 2780 & Forest & 2348 & 277 & 467 \\
\hline Others & 262 & 427 & 437 & 1126 & Others & 245 & 477 \\
\hline Agriculture & 480 & 901 & 1525 & 2906 & Agriculture & 118 & 479 \\
\hline Total & 3082 & 1641 & 2089 & 6812 & Total & 2711 & 1624 \\
\hline
\end{tabular}

Table 2: Types of changes between 1999 and 2013 for areas analysed.

\begin{tabular}{|c|c|c|c|c|c|c|}
\hline \multirow[t]{2}{*}{ S.No. } & \multicolumn{3}{|c|}{ Change trajectory } & \multirow{2}{*}{ Description LULC change classes } & \multirow[t]{2}{*}{ Area $\left(\mathrm{km}^{2}\right)$} & \multirow[t]{2}{*}{$\%$} \\
\hline & 1991 & 2001 & 2013 & & & \\
\hline 1 & Agriculture & Agriculture & Agriculture & Stable primary or secondary agriculture & 333.79 & 16.69 \\
\hline 2 & Other & Agriculture & Agriculture & Old and permanent agriculture regrowth & 11.57 & 0.58 \\
\hline 3 & Other & Agriculture & Other & Agriculture regrowth with new clearing & 9.88 & 0.49 \\
\hline 4 & Forest & Forest & Forest & Stable primary or secondary forest & 1086.57 & 54.33 \\
\hline 5 & Other & Forest & Forest & Old and permanent forest regrowth & 9.81 & 0.49 \\
\hline 6 & Other & Forest & Other & Forest regrowth with new clearing & 61.66 & 3.08 \\
\hline 7 & Agriculture & Other & Agriculture & Old agriculture clearing with regrowth & 8.32 & 0.42 \\
\hline 8 & Agriculture & Other & Other & Old and permanent agriculture clearing & 38.76 & 1.94 \\
\hline 9 & Other & Other & Other & Stable primary or secondary others & 439.64 & 21.98 \\
\hline 10 & Other & Other & Agriculture & Recent agriculture regrowth & - & - \\
\hline 11 & Other & Other & Forest & Recent forest regrowth & - & - \\
\hline
\end{tabular}

Table 3: Land-cover change trajectories in Olomouc and their descriptions 1991, 2001, 2013.

agriculture clearing area was approximately $2 \%$ of the total area. The 3-date change trajectories allow us to determine a single pixel's trajectory over time with more details (Table 3 ).

In the study many small fields were cleared and then were reforested (O-F-F), while many other small areas had O-F-O trajectories. Our field observations demonstrated that these were smallholder fields of shifting agriculture that were growing maize, pineapples, or other cash crops that were probably used in restaurants in Olomouc region. There was not any recent agriculture regrowth $(\mathrm{O}-\mathrm{O}-\mathrm{A})$ and recent forest regrowth $(\mathrm{O}-\mathrm{O}-\mathrm{F})$ class in the study area. But due to some specific location requirement old agriculture with regrowth (A-O-A) and old permanent agriculture clearing (A-O-O) was present (Figure 4).

After change trajectory calculation, distribution map of all the trajectories in the study area from 1991 to 2013 were generated. In the map green, brown and sky-blue pixels stand for "no change", while others stand for all kinds of "change". However, some trajectories would never happen and some others may take much small parts in all the trajectories so that they can be omitted. Through majority analysis with a $5 \times 5$ mask, the scattered trajectories with small count numbers in the whole area were assigned the value of neighbours in majority. It suggests that these changes were extensively induced by organized human activities, which coincides with the local practical situation. The study area suffers serious soil losses, which has brought great damage to the local residents. In order to conserve soil, the government has called on the local people to take measures to better the ecological environments.

During the first and second periods, the main trajectories were dominated by deforestation transitions that led to the decline of old growth forests and the increase of arboreous shrub land as a result of logging practices. A remarkable finding was, however, that the transition from old growth forest to arboreous shrub land changed from highly systematic in the first period to highly random in the second, similar to the majority of the transitions affecting native forest cover between 1991 and 2001. This finding suggests that the same type of transition (deforestation in this case) can be caused by either permanent or sudden forces that take place in the landscape. In the study area, the period of random changes (and coincidentally of a large amount of swap change) coincides with the beginning of the globalization process, characterized by trade liberalization policies and structural adjustment reforms which opened up the economy to international trade, favoured international investments, and reduced the role of the state in favour of market mechanisms to drive development [38]. The arrival of salmon and mussel farming and the transnational processing industries shows us how the globalization process manifested itself in the study area. During the 1991 and 2001's, rural migration rates and urban population increased, thus expanding the demand for firewood, the main product extracted from native forests in northern part. Added to this increased logging, the "woodchips exporting boom" (early 1990's to mid-2000's), led to abrupt deforestation, as indicated by the direct change from old growth and secondary forest to shrub lands through clear cutting.

\section{Discussion}

This work provides an empirical assessment of land cover change dynamics in Olomouc region. The results show that forest cover change involves a series of complex trajectories, some of which are cyclical and reversible, while others are more linear and permanent. These diverse trajectories are consistent with a highly dynamic landscape dominated by forms of small-holder land use that reflect heterogeneous livelihood strategies. In-depth analysis of the transition matrices allowed us to separate systematic from random transitions, which revealed unexpected dynamics. Usually, in rural landscapes dominated by peasant farming systems, forest cover loss is attributed to shifting cultivation. Our results, however, show that native forests have been systematically replaced by a range of other covers and land uses over time, and that agricultural expansion is just one of the direct causes of forest decline.

In the last period (2001-2013), most forest cover transitions became systematic again, driven by new forces that led to different cycles of old growth forest decline. The most systematic transition and relevant in terms of magnitude, was the change of old growth to secondary forest at an average annual rate. This very recent forest degradation relates mostly to peasant agricultural systems and can be associated to an increasing firewood demand from an expanding population in urban areas outside of the cities/villages [39].

The above land use change trajectories and trends indicate 
significantly increasing pressure on available land resources in the study area, leading to the cultivation of increasingly marginal areas, which again leads to dramatic soil fertility decline. It is imperative that these trends are taken into consideration when developing strategies for agricultural development in Olomouc. However, it may not absolutely represent the real land cover disturbance because of the difficulty of modelling the factors influencing this disturbance and the magnitude of human reaction capacity. On the other hand, the pressure exerted on forest depends on the socio-economic and tourist context and may change in the future, according to the disturbance that these societies were experienced. Land use/cover changes were mainly caused by human activities and natural forces.

Overall, the results reflect the conflicting interactions between physical and human systems in the study area. In this respect, a key question to address is how to generate the incentives that move individuals from conflicting relations with their natural system, toward more sustainable landscape transitions and trajectories without the regulatory presence of the government (e.g. a ban on logging). Worldwide, land is private property and its usufruct is an important right for the landowner, which implies its free use and also determines its value. The forest dynamics described in this study to systematic economic forces such as firewood and industrial timber demand. If these landowners continue to degrade their forest resources at the rates observed between 1991, 2001 and 2013, by 2020 few and small patches of old growth forest can be expected to remain [40].

\section{Conclusion}

In this research work, land cover change trajectories for three different dates from 1991 to 2013 were extracted from satellite imageries by object oriented classification method. Classification results were calibrated with ground truth trajectories. These results are useful to spatio-temporal variability of landscape pattern and their change trajectories with natural factors. Analysis based on these landscape trajectories demonstrates that major parts of land use/cover changes have been caused by human activities, most of which, under the direction of local government, have mainly led to virtuous change in the study area. This study was carried out on small study area with three major land cover classes. The significant body of data containing accurate spatial and thematic detail that was yielded by the analysis sheds considerable light on recent land cover and its dynamics. So in the later research, more influential factors would be taken into the analysis, including some human geographical factors and economic geographic factors, such as transport, social economy and so on.

\section{References}

1. Boori MS (2011) Avaliação de impacto ambiental e gestão dos recursos natuarias no estuário Apodi Mossoró, nordeste do Brasil. Federal University of Rio Grande do Norte, Brazil.

2. http://epp.eurostat.ec.europa.eu/portal/page/portal/agriculture/data/database

3. Brouwer FM (2001) The relation between agriculture, land use and policy in Europe. In Kaleidoscopic view on social scientific global change research in the Netherlands.

4. Eurostat (2012) Farm structure survey. Structure of agricultural holdings 2007. Luxembourg: European Communities.

5. Boori MS, Ferraro RR (2013) Microwave polarization and gradient ratio (MPGR) for global land surface phenology. Journal of Geology and Geosciences 2: 114.

6. Sklenicka P, Lhota T, Cecetka J (2002) Soil porosity along a gradient from forest edge to field. Die Bodenkultur 53: 191-197.

7. Boori MS, Amaro VE, Targino A (2012) Coastal risk assessment and adaptation of the impact of sea-level rise, climate change and hazards: A RS and GIS based approach in Apodi-Mossoro estuary, Northeast Brazil. International Journal of Geomatics and Geosciences 2: 815-832.

8. Skalos J, Engstova B (2010) Methodology for mapping non-forest wood elements using historic cadastral maps and aerial photographs as a basis for management. Journal of Environmental Management 91: 831-843.

9. Wang C, Jamison BE, Spicci AA (2010) Trajectory-based warm season grassland mapping in Missouri prairies with multi-temporal ASTER imagery. Remote Sensing of Environment 114: 531-539.

10. Boori MS, Amaro VE (2011) Natural and eco-environmental vulnerability assessment through multi-temporal satellite data sets in Apodi valley region, Northeast Brazil. Journal of Geography and Regional Planning 4: 216-230.

11. Kasperson JX, Kasperson RE, Turner BL (1995) Regions at Risk: Comparisons of Threatened Environments. United Nations University Press, Tokyo, Japan.

12. Boori MS, Amaro VE, Minora PLS, Torgino A (2010) Eco-environmental Vulnerability analysis by the remote sensing satellite data sets in Apodi Valley Region, Northeast Brazil. $6^{\text {th }}$ International Latin American Symposium on Physical Geography, Coimbra, Portugal.

13. Antrop M (2005) Why landscape of the past are important for the future Landscape Urban Plan 70: 21-34.

14. Voženílek V, Vondráková A, Brychtová A (2013) Datový model mapy formalizovaný způsob zápisu sestavení mapy z dat GIS.

15. Bolstad PV, Lillesand TD (1991) Rapid Maximum Likelihood classification Photogrammetric Engineering \& Remote Sensing 57: 67-74.

16. Boori MS, Amaro VE (2011) A remote sensing and GIS based approach for climate change and adaptation due to sea-level rise and hazards in ApodiMossoro estuary, Northeast Brazil. International Journal of Plant, Animal and Environmental Sciences 1: 14-25.

17. Dong Y, Forster B, Ticehurst C (1997) Radar backscatter analysis for urban environments. International Journal of Remote Sensing 18: 1351-1364.

18. Boori MS, Ferraro RR (2014) Global Land Cover classification based on microwave polarization and gradient ratio (MPGR). Geo-informatics for Intelligent Transportation (GIS Ostrava 2014) Technical University of Ostrava, Ostrava-Poruba, Czech Republic.

19. Jensen JR, Hodgson ME, Tullis JA, Raber GT (2004) Remote sensing of impervious surfaces and building infrastructure. Geo-Spatial Technologies in Urban Environments: 5-21.

20. Boori MS, Amaro VE, Vital H (2010) Coastal ecological sensitivity and risk assessment: A case study of sea level change in Apodi River (Atlantic Ocean), Northeast Brazil. International Journal of Environmental and Earth Sciences 1: $127-136$.

21. Hathout S (2002) The use of GIS for monitoring and predicting urban growth in East and West St Paul, Winnipeg, Manitoba, Canada. Journal of Environmental Management 66: 229-238.

22. Boori MS (2010) Coastal vulnerability, adaptation and risk assessment due to environmental change in Apodi-Mossoro estuary, Northeast Brazil. International Journal of Geomatics and Geosciences 1: 620.

23. Serra P, Pons X, Saurı D (2008) Land-cover and land-use change in a Mediterranean landscape: a spatial analysis of driving forces integrating biophysical and human factors. Applied Geography 28: 189-209.

24. Coppin P, Jonckheere I, Nackaerts K, Muys B, Lambin E (2004) Digital change detection methods in ecosystem monitoring: a review. International Journal of Remote Sensing 25: 1565-1596.

25. Singh A (1989) Digital change detection techniques using remotely sensed data. International Journal of Remote Sensing 10: 989-1003.

26. Nelson RF (1983) Detecting forest canopy changes due to insect activity using Landsat MSS. Photogrammetric Engineering \& Remote Sensing 49: 130-1314.

27. Boori MS, Amaro VE, Vital H (2010) Coastal ecological sensitivity and risk assessment: A case study of sea level change in Apodi River (Atlantic Ocean), Northeast Brazil. World Academy of Science, Engineering and Technology 48: 866 .

28. Johnson RD, Kasischke ES (1998) Change vector analysis: a technique for the multi-temporal monitoring of land cover and condition. International Journal of Remote Sensing 19: 411-426. 
Citation: Boori MS, Voženílek V (2014) Remote Sensing and Land Use/Land Cover Trajectories. J Geophys Remote Sensing 3: 123. doi:10.4172/21690049.1000123

29. Boori MS Amaro VE (2010) Detecting and understanding drivers of natural and eco-environmental vulnerability due to hydro geophysical parameters ecosystem and land use change through multispectral satellite data sets in Apodi estuarine Northeast Brazil. International Journal of Environmental Sciences 1: 543-557.

30. Hartter J Lucas C Gaughan AE Aranda LL (2008) Detecting tropical dry forest succession in a shifting cultivation mosaic of the Yucata'n Peninsula Mexico. Applied Geography 28: 134-149.

31. Boori MS, Amaro VE (2010) Land use change detection for environmental management using multi-temporal, satellite data in Apodi Valley of northeastern Brazil. Applied GIS International Journal 6: 1-15.

32. Hardin PJ, Jackson MW, Otterstrom SM (2007) Mapping, measuring, and modeling urban growth. Geo-spatial technologies in urban environments: 141 176.

33. Ridd MK, Liu JJ (1998) A comparison of four algorithms for change detection in an urban environment. Remote Sensing of Environment 63: 95-100.

34. Brus J, Boori MS, Vozenilek V (2013) Detection and visualizations of ecotones
- important landscape pattern under uncertainty. Journal of Earth Science and Climate Change 4: e108

35. Boori MS, Amaro VE (2011) A remote sensing approach for vulnerability and environmental change in Apodi valley region, Northeast Brazil. World Academy of Science, Engineering and Technology, International journal of Environmental, Earth Science and Engineering 5: 10-20.

36. Boori MS, Ferraro RR (2012) Northern Hemisphere snow variation with season and elevation using GIS and AMSR-E data. Journal of Earth Science and Climate Change S12: 001.

37. Hecht SB, Saatchi SS (2007) Globalization and forest resurgence: changes in forest cover in El Salvador. BioScience 57: 663-672.

38. Carmona A, Nahuelhual L, Echeverría C, Báez A (2010) Linking farming systems to landscape change an empirical and spatially explicit study in southern Chile. Agriculture Ecosystems and Environment 139: 40-50.

39. Marín SL, Nahuelhual L, Echeverría C, Grant WE (2011) Projecting landscape changes in southern Chile: simulation of human and natural processes driving land transformation. Ecological Modeling 222: 2841-2855. 